\title{
O PARAíSO SÃO OS OUTROS
}

\author{
Por Valter Hugo Mãe
}

estes nossos tempos onde somos marcados pela animosidade no mundo, no qual a frase popular de Sartre "O inferno são os outros" deixou de ser só uma reflexão e se tornou uma máxima, encontrarmo-nos com a obra de

JANICE RECHULSKI Instituto Sistemas Humanos, São Paulo/SP, Brasil
Valter Hugo Mãe, "O paraíso são os outros" é receber um convite para o resgate do amor no ser humano.

Através da voz da pequena Halla, o autor nos leva a pensar o humano em suas relações de amor e desamor, sobre o nosso ser, estar e fazer no mundo. A obra reflete sobre a necessidade que temos uns dos outros para conhecermos o nosso inferno e o nosso paraíso. Convoca-nos a entender a ética das relações entre humanos, entre os animais e entre os humanos e os animais. A ética, para Halla, seria possível por meio do amor, independente da sua forma - seja ele singelo, como o vínculo entre os animais, seja ele sublime, como o amor que ultrapassa os anos e vence o tempo:

Reparo desde pequena que os adultos vivem muito em casais. Mesmo que não sejam óbvios, porque algumas pessoas têm par, mas andam avulsas como as solteiras, há casais de mulher com homem e outros de mulher com mulher. Depois há casais de pássaros, coelhos, elefantes, besouros. Os pinguins são absurdamente fiéis, quero dizer: há também casais de pinguins e até de golfinhos. Tudo por causa do amor. (Mãe, 2018, p. 9).

Ah, outra coisa divertida é que alguns casais são formados por pessoas muito velhas. Pessoas muito velhas que se deixam ficar juntas. Chamase amor para sempre. Dura uma vida inteira e não cansa. Pelo contrário. Mesmo com cem anos, as pessoas agradecem sempre mais amor. Chegam a andar ainda à procura e muitas encontram. Nunca se torna tarde. Tarde é a metade do meio dos dias. (Mãe, 2018, p. 49).

São as observações, as constatações, as dúvidas e os pensamentos de Halla queiluminam nossa alma, resgatando algum fio de esperança no humano contemporâneo. Valter Hugo Mãe acredita nas práticas colaborativas; acredita que, apesar da improbabilidade dos casais, das dificuldades das famílias, das diferenças entre as pessoas que se cercam, somos melhores quando estamos juntos.

Acredito que as relações colaborativas são restauradoras da possibilidade de estar com o outro. É nesse encontro conversacional entre terapeuta aprendiz e cliente que surgem novas narrativas. Narrativas estas que podem ser transformadoras, onde ambos, num contexto de intimidade e confiança, acessam seu paraíso e podem ressignificar seu inferno. 
Ao findar sua história, o narrador se dirige à personagem explicando-lhe a importância do amor nas relações interpessoais e, acima de tudo, a importância dessas relações, que, na verdade, dão sentido à sua existência - fator este que pode ser pensado e levado para a terapia conversacional:

O inferno não são os outros, pequena Halla. Eles são o paraíso, porque um homem sozinho é apenas um animal. A humanidade começa nos que te rodeiam, e não exatamente em ti. Ser-se pessoa implica a tua mãe, as nossas pessoas, um desconhecido ou a sua expectativa. Sem ninguém no presente nem no futuro, o indivíduo pensa tão sem razão quanto pensam os peixes. Dura pelo engenho que tiver e perece como um atributo indiferenciado do planeta. Perece como uma coisa qualquer. (Mãe, 2018, p.57).

Nas conversações comigo mesma e com o outro, os livros se constituem em meus companheiros. São ampliadores de repertórios de possibilidades e enriquecem nossos diálogos, como muito bem apontou o poeta José Paulo Paes (19261988): "O livro não é aquilo que entra pelos olhos, é o que modifica seu olhar".

"O paraíso são os outros” é uma experiência relacional que nos modifica.

\section{REFERÊNCIAS}

Mãe, Valter Hugo (2018). O paraíso são os outros. Editora Biblioteca Azul (editado 2014 reeditado em 2018).

\section{JANICE RECHULSKI}

Psicóloga, terapeuta de casal, família e individual. Sócia-fundadora e formadora do Instituto Sistemas Humanos.

E-mail: janrechulski@hotmail.com 